\title{
THE EFFECT OF THE NITROGEN SOURCE TYPE ON THE GROWTH AND CONSUMPTION OF CRUDE GLYCEROL BY STREPTOMYCES HYGROSCOPICUS CH-7
}

Slavica B. Ilić ${ }^{1, *}$, Jovan T. Ćirić ${ }^{2}$ Gordana Gojgić-Cvijović ${ }^{3}$

${ }^{1}$ Faculty of Technology, Leskovac, University of Niš, Serbia

${ }^{2}$ Research and Development Center "ALFATEC", Niš, Serbia

3 Institute of Chemistry, Technology and Metallurgy, University of Belgrade, Belgrade, Serbia

In this paper we studied the effect of different amino acids (arginine, tryptophan, tyrosine, and phenylalanine) as nitrogen sources on the growth of actinomycete Streptomyces hygroscopicus $\mathrm{CH}-7$ and the consumption of crude glycerol, obtained as a by-product in the biodiesel production from sunflower oil. The highest biomass concentration $(9.5 \mathrm{~g} / \mathrm{L})$ was achieved using the basic medium and the medium with tryptophan $(9.2 \mathrm{~g} / \mathrm{L})$, while the crude glycerol consumption was the highest in the basic medium $(5.9 \mathrm{mg} / \mathrm{mL})$ and the medium with phenylalanine (3.3 $\mathrm{mg} / \mathrm{mL})$.
(ORIGINAL SCIENTIFIC PAPER)

UDC 579.22.547.426

DOI 10.5937/savteh2101041।
Keywords: nitrogen sources, Streptomyces hygroscopicus, crude glycerol, biodiesel production

\section{Introduction}

Streptomyces (family Streptomycetaceae and order Actinomycetales) are Gram-positive bacteria and represent $50 \%$ of the total population of soil actinobacteria. Although Streptomyces can be found in different habitats, most Streptomyces are mainly soil organisms. The soil $\mathrm{pH}$ is one of the important parameters that influence the growth and activity of Streptomyces in their natural environment [1].

As the soil has a very complex and variable ecological composition, streptomycetes have developed many adaptive mechanisms including the ability to form spores and hyphae with branched structure and to synthesize many secondary metabolites such as antibiotics. Secondary metabolites are not essential for their survival and they are usually synthesized in the stagnating or reproduction stage [2]. Streptomycetes produce many extracellular hydrolytic enzymes that enable the use of different substrates. Since streptomycetes produce the enzymes, such as cellulases, lignocellulase chitinases, and protease that decompose many of the macromolecules present in nature, they are major microorganisms participating in the carbon cycling or the formation of humus in the soil $[3,4]$.

The bacterium identified as Streptomyces hygroscopicus $\mathrm{CH}-7$ was isolated in 1974 from a sample of the Vojvodina soil. The isolated strain produces antibiotic substances that inhibit gram-positive bacteria, yeasts, and fungi. When grown in an appropriate liquid medium, this strain produces a mixture of antibiotics, wherein three antibiotics are isolated: polyether Nigericin, polyene Hexaene $\mathrm{H}-85$, and macrodiolide Azalomycine B (elaiophyline) [5-7].
Since antibiotic production depends on the strain and the medium composition, considerable efforts have been made to optimize the composition of the culture medium by varying carbon and nitrogen sources. The culture medium usually contains one or more carbon sources that the strain may assimilate. It may block or reduce the production of secondary metabolites, so the selection of a suitable carbon sources is very important for bacterial growth [8].

Glucose is the most commonly used carbon source for the microbial growth and the production of secondary metabolites [9]. Not only does it significantly promote the growth of the genus Streptomyces, but it is also a precursor for the biosynthesis of secondary metabolites. However, it can interfere with the production of numerous secondary metabolites. The repression effect is not yet fully understood, but it may be related to the glucose transport and phosphorylation. Species of the genus Streptomyces, including Streptomyce hygroscopicus, have the ability to consume glycerol as a carbon source in growth media [10-13]. Since glycerol can be obtained as a by-product in biodiesel production, its microbial valorization can be one of the ways to convert this cheap, biodegradable, non-toxic, non-irritating and recyclable substance into a product with an additional value. Crude glycerol, generated in the reaction of alkali-catalyzed transesterification, contains traces of soap, dirt from oil, and catalyst residues. Usually, crude glycerol is $80 \%$ of purity and presents a starting raw material in the production of pure (pharmaceutical) glycerol. Pharmaceutical glycerol has a very wide application in the medicine and cosmetic industries (9-27\%, depending on the continent),

\footnotetext{
*Author address: Slavica Ilić, University of Niš, Faculty of Technology, Bulevar oslobođenja 124, 16000 Leskovac, Serbia

E-mail: ilicslavica@yahoo.com

The manuscript received: March, 01, 2020.

Paper accepted: March, 15, 2021
} 
in the manufacture of explosives (3-15\%), tobacco (2$14 \%)$, resins $(14-32 \%)$, urethane $(6 \%)$, and cellophane $(5-24 \%)$, for the preparation of food and beverages, etc. [14]. The purification process is not often economically viable, and therefore, crude glycerol becomes a potential raw material for some bioprocesses [15].

In addition to carbon sources, nitrogen sources (amino acids, inorganic salts, organic substances) are also an important parameter for the growth of Streptomyces hygroscopicus and its antibiotic productivity. In most cases, there is a correlation between antibiotic production and biomass. It is evident that the optimal microbial growth is required for the optimal production of antibiotics. For the strain Streptomyces hygroscopicus $\mathrm{CH}-7$, it has been shown that amino acids, as a nitrogen source, have a stimulating effect on the growth and production of antibiotics. [16].

The present study deals with the influence of the nitrogen source type on the growth and consumption of crude glycerol by Streptomyces hygroscopicus $\mathrm{CH}$ 7. The main goal was to select the optimal amino acid among arginine, tryptophan, tyrosine, and phenylalanine that ensures ensures maximum bacterial growth and crude.

\section{Experimental}

\section{Chemicals}

The chemicals used for fermentation media are: Glucose (Merck, Germany), soybean meal (Banat, Vršac), $\mathrm{CaCO}_{3}$ (Alkaloid, Skopje), $\mathrm{NaCl}$ (Alkaloid, Skopje), $\mathrm{MgSO}_{4}$ (Merck, Germany), $\left(\mathrm{NH}_{4}\right)_{2} \mathrm{HPO}_{4}$ (Merck, Germany), $\mathrm{K}_{2} \mathrm{HPO}_{4}$ (Merck, Germany), amino acids (Merck,Germany). Crude glycerol was obtained from the production of biodiesel catalyzed by sunflower oil base [17].

\section{Microorganism}

The strain Streptomyces hygroscopicus $\mathrm{CH}-7$ (NCAIM(P) B-001336) was obtained from the Microbial collection at the Faculty of Chemistry and the Institute of Chemistry, Technology and Metalurgy in Belgrade, the University of Belgrade, Serbia. The culture was stored at $+4{ }^{\circ} \mathrm{C}$ in soybean meal medium containing glucose 15 $\mathrm{g} / \mathrm{L}$, soybean meal $10 \mathrm{~g} / \mathrm{L}, \mathrm{CaCO}_{3} 3 \mathrm{~g} / \mathrm{L}, \mathrm{NaCl} 3 \mathrm{~g} / \mathrm{L}$, and agar $2 \mathrm{~g} / \mathrm{L}(\mathrm{pH} 7.2)$.

\section{Fermentation media}

The fermentation media used a basal medium and a medium containing amino acids. The basal medium contained glycerol $15 \mathrm{~g} / \mathrm{L}$, soybean meal $10 \mathrm{~g} / \mathrm{L}, \mathrm{CaCO}_{3} 3$ $\mathrm{g} / \mathrm{L}, \mathrm{NaCl} 3 \mathrm{~g} / \mathrm{L}, \mathrm{MgSO}_{4} \times 7 \mathrm{H}_{2} \mathrm{O} 0.5 \mathrm{~g} / \mathrm{L},\left(\mathrm{NH}_{4}\right)_{2} \mathrm{HPO}_{4} 0.5$ $\mathrm{g} / \mathrm{L}$, and $\mathrm{K}_{2} \mathrm{HPO}_{4} 1 \mathrm{~g} / \mathrm{L}$. The medium with amino acids (arginine, tryptophan, tyrosine, or phenylalanine) contained glycerol $15 \mathrm{~g} / \mathrm{L}$, amino acids $10 \mathrm{~g} / \mathrm{L}, \mathrm{CaCO}_{3} 3 \mathrm{~g} / \mathrm{L}$, $\mathrm{NaCl}, \mathrm{MgSO}_{4} \times 7 \mathrm{H}_{2} \mathrm{O} 0.5 \mathrm{~g} / \mathrm{L},\left(\mathrm{NH}_{4}\right)_{2} \mathrm{HPO}_{4} 0.5 \mathrm{~g} / \mathrm{L}$, and $\mathrm{K}_{2} \mathrm{HPO}_{4} 1 \mathrm{~g} / \mathrm{L}$.

\section{Inoculum preparation}

Flasks $(250 \mathrm{ml}$ ) containing $50 \mathrm{ml}$ of either basal medium or amino acid-containing medium were inoculated with $0.1 \mathrm{ml}$ of spore suspension, fixed on a rotary shaker and incubated with shaking $(200 \mathrm{rpm})$ at $30^{\circ} \mathrm{C}[6,16]$.

\section{Fermentation procedure}

The fermentation medium was inoculated with $5 \%(\mathrm{v} / \mathrm{v})$ preculture after $48 \mathrm{~h}$ of growth and incubated at $30^{\circ} \mathrm{C}$ for $24 \mathrm{~h}$ under standard conditions of aeration and stirring $(200 \mathrm{rpm})$. Samples were taken from the fermentation medium $(10 \mathrm{~mL})$ as the fermentation process progressed and centrifuged (20 min, $3000 \mathrm{~min}^{-1}$ ) to separate the liquid from the biomass, which was used to determine glycerol and dry biomass. The liquid portion was filtered through a $0.45 \mu \mathrm{m}$ microfilter prior to analysis. The biomass was washed with distilled water and dried at $105^{\circ} \mathrm{C}$ to constant weight.

\section{Analytical methods}

The dry biomass (microbial growth) and glycerol concentration (consumption) were monitored during the fermentation. The growth of $\mathrm{S}$. hygroscopicus $\mathrm{CH}-7$ was monitored by measuring the dry biomass [16].

\section{Glycerol consumption}

The glycerol concentration in the supernatant was determined by HPLC method using a chromatograph (Agilent 1100 Series) equipped with an Aminex HPX-87H column. After applying $20 \mu \mathrm{L}$ of the sample, the elution was carried out with $5 \mathrm{mM} \mathrm{H}_{2} \mathrm{SO}_{4}$ at $50^{\circ} \mathrm{C}$ at a flow rate of $0.6 \mathrm{~mL} / \mathrm{min}$. Glycerol was detected by an IR detector, based on the retention time of pure glycerol. The concentration of glycerol was calculated using the standard line of pure glycerol. Samples of the liquid fermentation medium $\left(10 \mathrm{~mL}\right.$ ) were centrifuged (20 min. $\left.3000 \mathrm{~min}^{-1}\right)$ and the supernatant was filtrated through microfilters with a pore size of $0.45 \mu \mathrm{m}$.

\section{Results and Discussion}

To stimulate the bacterial growth and the crude glycerol consumption by $S$. hygroscopicus, the soybean meal used as a nitrogen source in the basal medium was replaced with amino acids (10 $\mathrm{g} / \mathrm{L})$. Pure glycerol was also used as in the control culture medium. Amino acids are well known as a good nitrogen source $[18,19]$ and tryptophan, arginine, and phenylalanine have already been used to stimulate growth and antibiotics production by Streptomyces hygroscopicus $\mathrm{CH}-7$ strain $[12,20]$.

The fermentation dynamics is shown in Figures 1-4.

Figures 1 and 2 show the changes of the dry biomass concentration during the fermentation. Regardless of the nitrogen source, the concentration of dry biomass increased during the first $72 \mathrm{~h}$ of the fermentation, and then it began to decrease. Except in the media with tyrosine and crude glycerol as a carbon source, the maximum value $(7.9 \mathrm{~g} / \mathrm{L})$ was achieved after $96 \mathrm{~h}$ of fermentation. 
The lowest growth $(8 \mathrm{~g} / \mathrm{L})$ was observed in the media with pure glycerol as a carbon source and tyrosine as a nitrogen source after $72 \mathrm{~h}$ of fermentation.

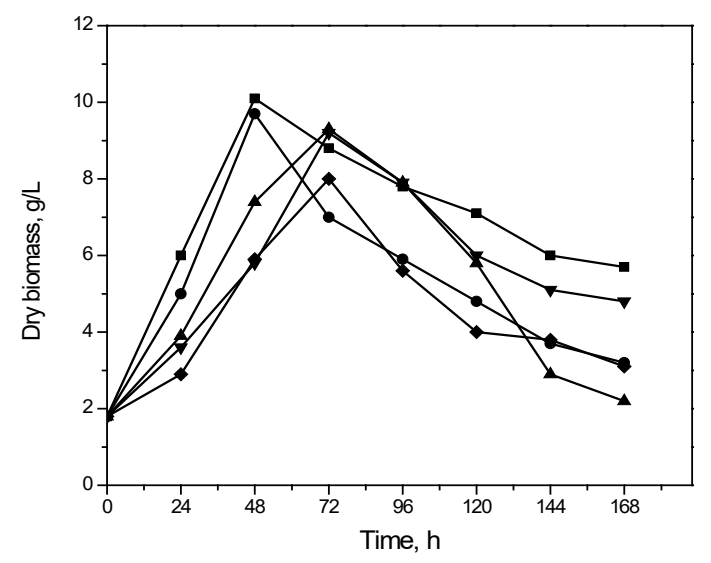

Figure 1. The changes of the dry biomass concentration during the fermentation of Streptomyces hygroscopicus $\mathrm{CH}-7$ using pure glycerol as a carbon source in the basal medium ( and media with tryptophan $(\bullet)$; arginine $(\boldsymbol{\Delta})$; tyrosine $(\bullet)$; and phenylalanine $(\boldsymbol{\nabla})$

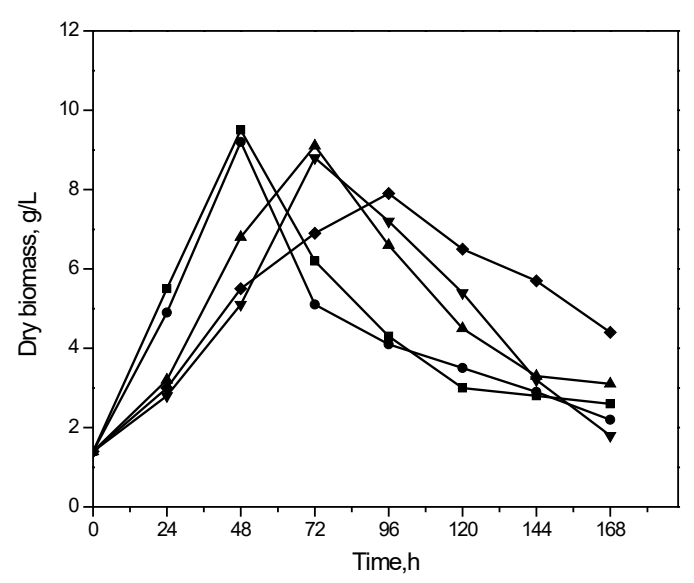

Figure 2. The changes of the dry biomass concentration during the fermentation of Streptomyces hygroscopicus $\mathrm{CH}-7$ using crude glycerol as a carbon source in basal medium ( $\mathbf{})$ and media with tryptophan $(\bullet)$; arginine $(\boldsymbol{\Delta})$; tyrosine $(\bullet)$; and phenylalanine $(\boldsymbol{\nabla})$

The highest concentration of dry biomass $(9.5 \mathrm{~g} / \mathrm{L})$ with crude glycerol was achieved after $48 \mathrm{~h}$ in the medium with soyabean meal as a nitrogen source, which is $6 \%$ less than that obtained with pure glycerol (10.1 $\mathrm{g} / \mathrm{L}$ ) or $8 \%$ less than in the medium with pure glycerol under growth conditions already applied in a previous study [12]. In the medium containing tryptophan, the maximum value $9.7 \mathrm{~g} / \mathrm{L}$ for pure glycerol and $9.2 \mathrm{~g} / \mathrm{L}$ for crude glycerol were obtained after $48 \mathrm{~h}$. The maximum values of dry biomass concentration with crude glycerol in the media with arginine $(9.1 \mathrm{~g} / \mathrm{L})$, phenylalanine $(8.8$ $\mathrm{g} / \mathrm{L})$, and tyrosine $(7.9 \mathrm{~g} / \mathrm{L})$ achived after $72 \mathrm{~h}$ were lower for $2.1 \%, 4.3 \%$, and $1.2 \%$ than the values obtained with pure glycerol. Compared to the medium with tryptophan, a slightly lower growth was achieved in the media with arginine and phenylalanine, while a significantly lower growth was achieved in the medium with tyrosine, when crude and pure glycerol were used as a carbon source.

The change of glycerol concentration during the fermentation process is shown in Figures 3 and 4.

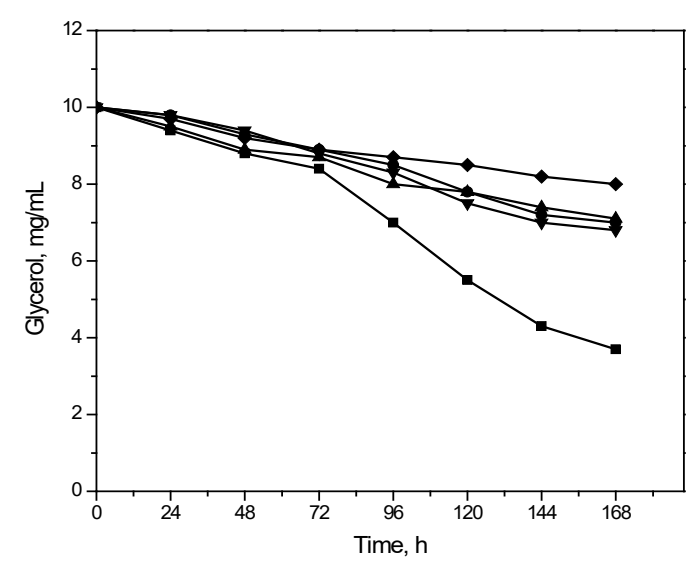

Figure 3. The changes in the glycerol concentration during the fermentation of Streptomyces hygroscopicus $\mathrm{CH}-7$ with pure glycerol in the basal medium ( $\mathbf{})$ and media with: tryptophan $(\bullet)$; arginine $(\boldsymbol{\Delta})$; tyrosine $(\bullet)$; and phenylalanine $(\boldsymbol{\nabla})$

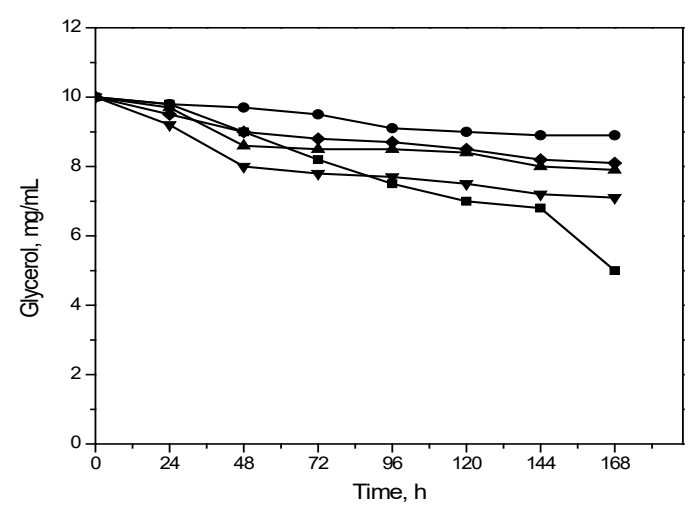

Figure 4. The changes in the glycerol concentration during the fermentation of Streptomyces hygroscopicus $\mathrm{CH}-7$ with crude

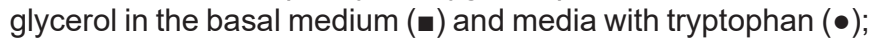
arginine $(\boldsymbol{\Delta})$; tyrosine $(\bullet)$; and phenylalanine $(\boldsymbol{\nabla})$

During the fermentation process, the concentration of glycerol decreased constantly in all media.The highest consumption of pure $(6.5 \mathrm{mg} / \mathrm{mL})$ and crude $(5.9$ $\mathrm{mg} / \mathrm{mL}$ ) glycerol were achieved in media with soyabean meal and phenylalanine $(3.7 \mathrm{mg} / \mathrm{mL}$ pure glycerol and $3.3 \mathrm{mg} / \mathrm{mL}$ crude glycerol). The lowest consumption of crude glycerol $(1.4 \mathrm{mg} / \mathrm{mL})$ was achieved in the medium with tryptophan, while in the media with pure glycerol, the lowest consumption was achieved using tyrosine 
$(1.6 \mathrm{mg} / \mathrm{mL})$ as a nitrogen source.

In the media with arginine and phenylalanine a significantly higher consumption of crude glycerol was achieved, compared to the medium with tryptophan. In the medium containing tyrosine, the consumption of crude glycerol was higher than the consumption of pure glycerol. Table 1 shows the effect of tryptophan, arginine, tyrosine, and phenylalanine on the dry biomass concentration and the total consumption of pure and crude glycerol.

Table 1. The effect of amino acids as a nitrogen source on the maximum dry biomass concentration $\left(X_{\max } P ; X_{\max }{ }^{C}\right)$ and consumption of glycerol $\left(\Delta_{\text {glyc }}{ }^{P} ; \Delta_{\text {glyc }}{ }^{C}\right)$ in media with pure $\left(-{ }^{P}\right)$ and crude $\left({ }^{\mathrm{C}}\right)$ glycerol

\begin{tabular}{|c|c|c|c|c|c|c|}
\hline \multirow{2}{*}{ Nitrogen source } & \multicolumn{2}{|c|}{$X_{\max }^{\mathrm{P}} \quad X_{\max }{ }^{\mathrm{C}}$} & \multicolumn{2}{|c|}{$\Delta_{g / y c} c^{P}$} & \multicolumn{2}{|c|}{$\Delta_{g / y c} c^{C}$} \\
\hline & $\mathrm{g} / \mathrm{L}$ & $g / L$ & $(\mathrm{mg} / \mathrm{mL})$ & $\%$ & $(\mathrm{mg} / \mathrm{mL})$ & $\%$ \\
\hline Soybean meal,10 g/L & 10.1 & 9.5 & 6.523 & 65 & 5.957 & 59 \\
\hline Tryptophan, $10 \mathrm{~g} / \mathrm{L}$ & 9.7 & 9.2 & 2.549 & 25 & 1.416 & 14 \\
\hline Arginine, $10 \mathrm{~g} / \mathrm{L}$ & 9.3 & 9.1 & 3.357 & 33 & 2.785 & 27 \\
\hline Tyrosine, $10 \mathrm{~g} / \mathrm{L}$ & 8.0 & 7.9 & 1.635 & 16 & 1.813 & 18 \\
\hline Phenylalanine, $10 \mathrm{~g} / \mathrm{L}$ & 9.2 & 8.8 & 3.756 & 37 & 3.312 & 33 \\
\hline
\end{tabular}

\section{Conclusion}

The strain Streptomyces hygroscopius $\mathrm{CH}-7$ shows the greatest growth in the medium with soybean meal $(9.5 \mathrm{mg} / \mathrm{mL})$ and tryptophane $(9.2 \mathrm{~g} / \mathrm{L})$ as nitrogen sources and crude glycerol as a carbon source. The greatest consumption of crude glycerol $(5.9 \mathrm{mg} / \mathrm{mL})$ was achieved in the medium with soyabean meal (5.9 $\mathrm{mg} / \mathrm{mL})$ and phenylalanine $(3.3 \mathrm{mg} / \mathrm{mL})$. Higher growth and consumption were observed in all media with pure glycerol, except in the medium with tyrosine, where the consumption of crude glycerol was $12 \%$ higher than the consumption of pure glycerol.

\section{Acknowledgements}

Republic of Serbia - Ministry of Education, Science and Technological Development, Program for financing scientific research work, number 451-03-9/202114/200133.

\section{Reference}

[1] E. A. Barka, P. Vatsa, L. Sanchez, N. Gaveau-Vaillant, C. Jacquard, H. P. Klenk, C. Clément, Y. Ouhdouch, G.P. van Wezeld, Taxonomy, Physiology, and Natural Products of Actinobacteria, Microbiology and Molecular Biology Reviews, 80 (2016) 1-43.

[2] A. L. Demain, A. Fang, The natural functions of secondary metabolites, Advances in Biochemical Engineering/ Biotechnology, 69 (2000) 1-39.

[3] H. Schrempf, Streptomycetaceae: Life Style, Genome, Metabolism and Habitats, in: Encyclopedia of Life Sciences (ELS), Editor John Wiley \& Sons Ltd: Chichester, 2008.

[4] S. Gopalakrishnan, V. Srinivas, S. L. Prasanna, Beneficial Microbes in Agro-Ecology, (2020) Chapter 5: Streptomyces.
[5] J. Vučetić, G. Gojgić-Cvijović, I. Karadžić, The identification of the polyether antibiotic produced by Actinomyces sp., Journal of the Serbian Chemical Society, 56 (1991) 581586.

[6] J. Vučetić, I. Karadžić, G. Gojgić-Cvijović, E. Radovanović, Improving hexaene $\mathrm{H}-85$ production by Streptomyces hygroscopicus, Journal of the Serbian Chemical Society, 59 (1994) 973-983.

[7] I. Karadžić, G. Gojgić-Cvijović, J. Vučetić, Hexaene H-85, A hexaene $\mathrm{H}-85$ macrolide complex, Journal of Antibiotics, 12 (1991) 1452-1453.

[8] J. V. Moreira, S. C. M. Silva, M. A. Cremasco, Evaluation of carbon:nitrogen ratio in semi-defined culture medium to tacrolimus biosynthesis by Streptomyces tsukubaensis and the effect on bacterial growth, Biotechnology Reports, 26 (2020) 1-6.

[9] J. Spizek, P. Tichy, Some aspects of overproduction of secondary metabolites, Folia Microbiologica, 40 (1995) 43-50.

[10] E. Jonsbu, M. Mcintyre, J. Nielsen, The influence of carbon sources and morphology on nystatin production by Streptomyces noursei, Journal of Biotechnology, 95 (2002) 133-144.

[11] V. Gesheva, V. Ivanova, R. Gesheva, Effects of nutrients on the production of AK-111-81macrolide antibiotic by Streptomyces hygroscopicus, Microbiological Research, 160 (2005) 243-248.

[12] J. T. Ćirić, S. B. Ilić, S. S.Konstantinović, V. B. Veljkovic, G. Gojgić-Cvijović, D. S. Savić, The fermentation of glycerol by Streptomyces hygroscopius $\mathrm{CH}-7$ bacteria, Advanced Technologies, 2 (2012) 20-25.

[13] S. B. Ilić, S. S. Konstantinović, G. Gojgić-Cvijović, D. S. Savić, V. B. Veljković, The impact of glycerol and some carbohydrates on antibiotic production by Streptomyces hygroscopicus $\mathrm{CH}-7$, Medicinal Chemistry Research, 22 (2013) 934-937.

[14] S. Papanikolaou, S. Fakas, M. Fick, I. Chevalot, M. G. Panayotou, M. Komaitis, Biotechnological valorisation of raw glycerol discharged after bio-diesel (fatty acid methyl esters) manufacturing process: production of 1,3-propanediol, citric acid and single cell oil, Biomass 
and Bioenergy, 32 (2008) 60-71.

[15] T. Willke, K. Vorlop, Biotransformation of glycerol into 1,3-propanediol, European Journal of Lipid Science and Technology, 110 (2008) 831-840.

[16] S. Ilić, Uticaj sastava i reoloških svojstava hranljive podloge na kinetiku produkcije antibiotika pomoću bakterije Streptomyces hygroscopicus $\mathrm{CH}-7$, Thesis, Tehnološki fakultet, Univerzitet u Nišu, Leskovac, 2010.

[17] A. V. Marjanović, O. S. Stamenković, Z. B. Todorović, M. L. Lazić, V. B. Veljković, Kinetics of the base-catalyzed sunflower oil ethanolysis, Fuel, 89 (2010) 665-671.
[18] M. Mahesh, N. Meenakshi, Effect of carbon and nitrogen source for the production of tetracycline analysis by using HPLC, International Journal of Advanced Biotechnology and Research, 4 (2013) 218-223.

[19] S. Rattleff, Heterologous protein production in Streptomyces lividans, Thesis, Technical University of Denmark, Denmark, 2013.

[20] S. B. Ilić, S. S. Konstantinović, D. S. Savic, V. B. Veljković, G. Gojgić-Cvijović, The impact of Schiff bases on antibiotic production by Streptomyces hygroscopicus, Medicinal Chemistry Research, 19 (2010) 690-697.

Izvod

\section{UTICAJ IZVORA AZOTA NA RAST I POTROŠNJU SIROVOG GLICEROLA KOD BAKTERIJE STREPTOMYCES HYGROSCOPICUS CH-7}

Slavica B. Ilić ${ }^{1}$, Jovan T. Ćirić2 ${ }^{2}$ Gordana Gojgić-Cvijović ${ }^{3}$

\footnotetext{
${ }^{1}$ Tehnološki fakultet, Leskovac, Univerzitet u Nišu, Srbija

2Istraživačko-razvojni centar "ALFATEC", Niš, Srbija

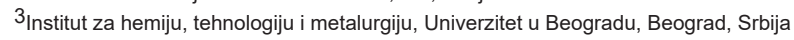

U ovom radu je ispitan efekat različitih aminokiselina (arginin, triptofan, tirozin i fenilalanin), kao izvora azota na rast Streptomyces hygroscopicus $\mathrm{CH}-7$ i potrošnju sirovog glicerola, dobijenog kao nusproizvoda u proizvodnji biodizela iz suncokretovog ulja, pri čemu je izvršeno poređenje sa konvencionalnim izvorom azota kao što je sojino brašno. Najveći rast $(9,5 \mathrm{~g} / \mathrm{L})$ postignut je u osnovnom medijumu i medijimu sa triptofanom $(9,2 \mathrm{~g} / \mathrm{L})$, dok je potrošnja sirovog glicerola najveća u osnovnom medijimu $(5,9 \mathrm{mg} / \mathrm{mL})$ i medijumu sa fenilalaninom $(3,3 \mathrm{mg} / \mathrm{mL})$.
(ORIGINALNI NAUČNI RAD)

UDK 579.22.547.426

DOI 10.5937/savteh2101041।

Ključne reči: izvori azota, Streptomyces hygroscopicus, sirovi glicerol, proizvodnja biodizela 